\title{
SUBCLINICAL MASTITIS IN DAIRY CAMELS IN ALGERIA: COMPARISON OF SCREENING TESTS
}

\author{
Leyla HADEF ${ }^{1,2}$, Hebib AGGAD ${ }^{1,3}$, Brahim HAMAD $^{1,2}$, Mohamed Said MAHMOUD ${ }^{1}$, \\ Aicha ADAIKA ${ }^{2}$
}

Received March 30, 2016; accepted December 10, 2016.

Delo je prispelo 30. marca 2016, sprejeto 10. decembra 2016.

\section{Subclinical mastitis in dairy camels in Algeria: Comparison of screening tests}

The aim of the present study was to determine a threshold values and to assess the effectiveness of four indirect tests for the diagnosis of subclinical mastitis in dairy camels comparing with bacteriological culture. One hundred fifty three milk samples from 17 lactating camels were subjected to bacteriological culture, where 84 milk samples were positive, 47 were negative and 22 samples were considered as contaminated. A total of 131 milk samples were screened by $\mathrm{pH}$, electrical conductivity (EC), California mastitis test (CMT) and somatic cell count (SCC). The good combination of sensitivity and specificity were obtained with a threshold of $6.55,7.2 \mathrm{mS} / \mathrm{cm}$, score trace was considered as CMT (+) and 240000 cells/ml for the four tests, respectively. The sensitivity of the SCC, $\mathrm{pH}, \mathrm{EC}$ and CMT was $72.61,66.66,47.61$ and $39.28 \%$; the specificity $70.21,38.02$, 59.57 and $72.34 \%$; percentage accuracy $71.75,51.14,51.90$ and $51.14 \%$; and positive predictive value $81.33,47.61,67.79$ and $71.73 \%$, respectively. The SCC was significantly correlated with bacteriological culture $(r=0.415, p<0.05)$. Kappa value of SCC was higher than that of other tests $(\mathrm{SCC}>\mathrm{CMT}>\mathrm{EC}>\mathrm{pH}$ ). In conclusion, the results suggest that the SCC was the most accurate, reliable, diagnostic method compared to other tests used in this study after cultural isolation for the detection of subclinical mastitis in dairy camel under field conditions.

Key words: camels; dromedaries; Camelus dromedarius; lactation; subclinical mastitis; screening tests; indirect tests; $\mathrm{pH}$ value; electrical conductivity; California Mastitis Test; somatic cell count; bacteriological test

\section{Subklinični mastitis pri mlečnih kamelah v Alžiriji: primerjava presejalnih testov}

Namen te študije je bil določiti mejne vrednosti in preveriti učinkovitost štirih posrednih testov za diagnozo subkliničnega mastitisa pri kamelah v primerjavi z bakteriološko kulturo. Sto triinpetdeset vzorcev mleka 17 kamel v laktaciji smo analizirali s kultivacijsko metodo, kjer je bilo 84 vzorcev mleka pozitivnih, 47 je bilo negativnih, 22 vzorcev pa je bilo okuženih. Na skupno 131 vzorcih mleka smo izmerili $\mathrm{pH}$ vrednost, električno prevodnost (EC) in število somatskih celic (SCC) ter opravili Kalifornijski test za mastitis (CMT). Dobro kombinacijo občutljivosti in specifičnosti smo dobili pri mejnih vrednostih: za pH 6,55, električno prevodnost 7,2 $\mathrm{mS} / \mathrm{cm}$, pozitivnim izidom CMT (+) in 240.000 somatskimi celicami na ml mleka. Občutljivost testa za SCC je bila 72,61, za pH 66,66, za EC 47,61 in za CMT 39,28 \%. Specifičnost testov se je gibala med 38,02 in $72,34 \%$; natančnost med 51,14 in $71,75 \%$ in pozitivna napovedna vrednost med 47,61 in $81,33 \%$. SCC je bilo statistično značilno povezano z bakteriološko kulturo $(r=0,415, p<0,05)$. Kapa vrednost za SCC je bila višja kot pri drugih testih (SCC > $\mathrm{CMT}>\mathrm{ES}>\mathrm{pH}$ ). Rezultati kažejo, da je v praktičnih pogojih reje SCC med primerjanimi metodami najnatančnejša in najbolj zanesljiva metoda za določanje subkliničnega mastitisa pri kamelah v primerjavi z bakteriološko metodo osamitve povzročiteljev mastitisa.

Ključne besede: enogrbe kamele; Camelus dromedaries; laktacija; subklinični mastitis; presejalni testi; posredni testi; pH vrednost; električna prevodnost; Kalifornijski test za mastitis; število somatskih celic; bakteriološki test

1 University of Tiaret, Laboratory of Hygiene and Animal Pathology, BP 75 Tiaret, 14000. Tiaret, Algeria

2 University El-Oued, Faculty Nature and life sciences, 39000. El-Oued, Algeria

3 Corresponding author: e-mail: h_aggad@yahoo.com 


\section{INTRODUCTION}

Many reports revealed that lactating camel can get mastitis easily (Abdel Gadir et al., 2006; Alamin et al., 2013; Al-Juboori et al., 2013), especially in its subclinical form (Hawari and Hassawi, 2008; Ahmed et al., 2011; Alamin et al., 2013; Husein et al 2013). Subclinical mastitis causes suffering of the animal, reduces milk yield, alters milk properties, impairs preservation and processing and represents a public health concern for consumers of camel milk (Tibary and Anouassi, 2000; Saleh and Faye, 2011).

Clinical mastitis in camel can be detected without special tests, by physical examination of the udder and milk (Abdurahman, 1995). However, sub-clinical mastitis refers to the existence of inflammation in the absence of gross signs (Bekele and Molla, 2001).

Detection of subclinical mastitis is difficult and depends upon various test procedures aimed at detecting the cause or the products of inflammation in milk. Cultural examination is considered the golden standard in order to establish reliable opinion about infection status of the udder (Tuteja et al., 2013).

Different methods have been suggested for detection of subclinical mastitis in camels, such as somatic cell count (SCC), California mastitis test (CMT) (Saleh and Faye 2011; Alamin et al., 2013; Ali et al., 2016), electrical conductivity (Eberlein, 2007; Ali et al., 2016) and pH estimation (Tuteja et al 2003; Ali et al., 2016).

These various tests are based upon detection of products of inflammation or changes in milk and have a well established role as screening test for predicting disease status of mammary gland in cattle, sheep and goat but their relevance for application to the camel is less known. Therefore, the aim of this study was to optimize and determine threshold values for $\mathrm{pH}$, electrical conductivity, California mastitis test and somatic cell counts and also to evaluate the effectiveness of these methods for the diagnosis of subclinical mastitis in dairy camel in comparison with microbiological culture.

\section{MATERIALS AND METHODS}

\subsection{SAMPLE COLLECTION}

The study was carried out on 17 dairy camels (Camelus dromedarius) from the south-East of Algeria. Between November 2014 and September 2015, a total of 153 milk samples were collected during the routine morning milking.

Udders of the camels were examined visually and by palpating for the presence of any lesions, such as redness, pain, heat, and swelling. Moreover, milk samples from each animal were taken and checked for any change in color and consistency.

The teat end was then scrubbed with a cotton wool wetted with $70 \%$ alcohol. After the teat-end had dried, the first strip was discarded and then approximately 50 $\mathrm{ml}$ of milk was collected into sterile bottles.

The samples were immediately transported on ice to the laboratory where they were examined using the $\mathrm{pH}$, EC, SCC, CMT and the milk bacteriological culture.

\subsection{MEASUREMENT OF $\mathrm{pH}$}

The $\mathrm{pH}$ of each milk sample was measured by digital pH-meter (Hanna HI 99161, Romania). The pH meter was calibrated in buffers of $\mathrm{pH} 4$ and 7 .

\section{3 ELECTRICAL CONDUCTIVITY (EC) TEST}

The Electrical conductivity of milk samples (mS/ $\mathrm{cm}$ ) was detected by electrical conductivity meter (Hanna EC 215). The device was calibrated using standard buffer solutions.

\section{4 CALIFORNIA MASTITIS TEST (CMT)}

Sub-clinical mastitis was diagnosed based on CMT results and the nature of coagulation and viscosity of the mixture (milk and CMT), which shows the presence and severity of the infection, respectively. Before sample collection for bacteriological examination, milk samples were examined for visible abnormalities, they were screened by CMT according to Quinn et al. (1999) from each animal, a squirt of milk sample was placed in each of the cups on CMT paddle and an equal amount of $3 \%$ CMT reagent was added to each cup and mixed well.

\subsection{SOMATIC CELL COUNT (SCC)}

Somatic cell counts were determined according to Weisen (1974) using the microscopic count. The method involves diluting the sample of milk to $1 / 10$ with Lazarus liquid. The suspension was homogenized and cells counted. In a drop between slide and cover slip, after eliminating the first 3 to 4 drops of the mixture. The cell concentration (cells $/ \mathrm{ml}$ ) was determined using a hemocytometer (Thoma cell) examined at a magnification 40x.

Three various threshold values for $\mathrm{pH}$, electrical conductivity and somatic cell counts were used to 
evaluate the effectiveness of these methods on screening of subclinical mastitis by evaluating its sensitivity (SE), specificity (SP), the positive predictive value (PPV) and negative predictive value (NPV) in comparison with bacterial culture. However, low threshold scores were used to assess the effectiveness of CMT test.

\subsection{BACTERIOLOGICAL EXAMINATIONS}

All milk samples, were randomly selected and used for bacteriological analysis. A loopful of each milk sample was streaked on defibrinated sheep (5\%) blood agar, nutrient agar, BCP (Bromcresol Purple Lactose) agar, and Chapman agar. Plates were incubated at $37^{\circ} \mathrm{C}$ for $48 \mathrm{~h}$. Grown colonies were subjected to the following tests as recommended by the National Mastitis Council (NMC, 1987): morphology, haemolysis pattern, Gram stain and biochemical classic tests. Samples with a growth of 5 or more identical colonies were considered positive for subclinical mastitis (1997; Pradieé et al., 2012). The growth of two or more morphological types (> 5 UFC per type) was considered as contamination and the result was excluded from the analysis (Gonzalo et al., 2005; Pradieé et al., 2012).

\subsection{STATISTICAL ANALYSIS}

Statistical analyses were performed using SPSS software (Version 16). The results were considered significant if the associated $p$ value was $<0.05$.

Sensitivity (Sn), specificity (Sp), positive predictive value (PPV), negative predictive value (NPV) and the accuracy of tests were calculated using standard two-bytwo contingency tables.

The following formulas were used for diagnostic test evaluation:

Sensitivity is the proportion of truly diseased that had the test positive and it was calculated as:

Sensitivity $=\mathrm{TP} / \mathrm{TP}+\mathrm{FN} \times 100$.

Specificity is the proportion of truly non-diseased that had the test negative and it was calculated as:

Specificity $=\mathrm{TN} / \mathrm{FP}+\mathrm{TN} \times 100$.

Positive predictive value is the probability that a disease is present in animals with positive test results. It was calculated as:

Positive predictive values $=\mathrm{TP} / \mathrm{TP}+\mathrm{FP} \times 100$.

Negative predictive value is the probability that the disease is absent in animals with negative test results. It was calculated as:

Negative predictive values $=\mathrm{TN} / \mathrm{FN}+\mathrm{TN} \times 100$.

Where: $\mathrm{TP}=$ true positive, $\mathrm{FP}=$ false positive, $\mathrm{TN}=$ true negative, $\mathrm{FN}=$ false negative.

The Kappa and Chi-square statistical analysis were used to determine the level of agreement between the diagnostic tests and bacterial culture.

Kappa values above 0.7 indicated an excellent agreement, whereas values between 0.4 and 0.7 indicated a moderate agreement. Values under 0.4 indicated a poor agreement. The correlation was calculated by the Phi test. The correlation index was classified as high $(r>0.7)$, me$\operatorname{dium}(0.5<r<0.7)$ and low $(r<0.5)$.

\section{RESULTS}

A total of 153 samples from 17 animals were examined with cultural examination, 84 samples were classified as positive (growth of 5 or more identical colonies), 47 samples were taken as negative (there was no growth) and 22 samples were considered as contamination (growth of two or more morphological types).

The sensitivity, specificity, predictive value and accuracy of various thresholds used for $\mathrm{pH}, \mathrm{EC}, \mathrm{CMT}$ and SCC tests, when cultural test was taken as standard are shown in Table 1, 2, 3 and 4 respectively.

The results of the study showed that the good combination of sensitivity, specificity, positive predictive value and negative predictive value of $\mathrm{pH}$ test was obtained while using a threshold of 6.55 , with values of $66.66 \%$, $38.02 \%, 47.61 \%$ and $57.44 \%$, respectively (Table 1 ).

For electrical conductivity, the good combination of sensitivity, specificity, positive predictive value and negative predictive value were observed while using a threshold of $7.2 \mathrm{mS} / \mathrm{cm}$, with values of $47.61 \%, 59.57 \%$, $67.79 \%$ and $38.88 \%$, respectively (Table 2).

Table 1: Analysis of the $p H$ values in comparison with bacterial culture

Preglednica 1: Analiza $p H$ vrednosti $v$ primerjavi $z$ bakteriološko kulturo

\begin{tabular}{lrll}
\hline & \multicolumn{3}{l}{$\mathrm{pH}$ threshold values } \\
\cline { 2 - 4 } Values observed & $\geq 6.40$ & $\geq 6.55$ & $\geq 6.60$ \\
\hline Sensitivity (\%) & 62.06 & 66.66 & 65.11 \\
Specificity (\%) & 20.00 & 38.02 & 36.36 \\
Positive predictive value (\%) & 85.71 & 47.61 & 33.33 \\
Negative predictive value (\%) & 6.38 & 57.44 & 68.08 \\
Accuracy (\%) & 57.25 & 51.14 & 45.80 \\
\hline
\end{tabular}


Table 2: Analysis of the electrical conductivity values in comparison with bacterial culture

Preglednica 2: Analiza električne prevodnosti v primerjavi z bakteriološko kulturo

\begin{tabular}{llll}
\hline & \multicolumn{3}{l}{$\begin{array}{l}\text { Electrical conductivity } \\
\text { threshold values }(\mathrm{mS} / \mathrm{cm})\end{array}$} \\
\cline { 2 - 4 } Values observed & $\geq 6.5$ & $\geq 7.2$ & $\geq 7.5$ \\
\hline Sensitivity (\%) & 59.52 & 47.61 & 31.32 \\
Specificity (\%) & 36.17 & 59.57 & 78.72 \\
Positive predictive value (\%) & 62.5 & 67.79 & 72.22 \\
Negative predictive value (\%) & 33.33 & 38.88 & 39.36 \\
Accuracy (\%) & 51.14 & 51.90 & 48.46 \\
\hline
\end{tabular}

The results indicated that the good combination of sensitivity, specificity, positive predictive value and negative predictive value of CMT test was obtained while considered score trace as CMT positive, with values of $39.28 \%, 72.34 \%, 71.73 \%$ and $40 \%$ respectively (Table 3).

Table 3: Analysis of the California mastitis test values in comparison with bacterial culture Preglednica 3: Analiza rezultatov kalifornijskega testa za mastitis v primerjavi z bakteriološko kulturo.

\begin{tabular}{lll}
\hline & \multicolumn{2}{l}{ California mastitis test threshold values (cells/ml) } \\
\cline { 2 - 3 } Values observed & $\begin{array}{l}\text { Score trace was consid- } \\
\text { ered as CMT (-) }\end{array}$ & $\begin{array}{l}\text { Score trace was consid- } \\
\text { ered as CMT }(+)\end{array}$ \\
\hline Sensitivity (\%) & 11.90 & 39.28 \\
Specificity (\%) & 97.87 & 72.34 \\
Positive predictive value (\%) & 90.90 & 71.73 \\
Negative predictive value (\%) & 38.83 & 40 \\
Accuracy (\%) & 42.74 & 51.14 \\
\hline
\end{tabular}

The best combination of sensitivity, specificity, positive predictive value and negative predictive value of somatic cell count test was recorded while using a threshold of 240,000 cells $/ \mathrm{ml}$, with values of $72.61 \%, 70.21 \%$, $81.33 \%$ and $58.92 \%$, respectively (Table 4 )

The comparison of considered thresholds characteristics, agreement and correlation values of various indirect tests in comparison with bacterial culture are given in Table 5.

The results showed that among the four tests, the SCC had the highest sensitivity (72.61\%), followed by pH (66.66 \%), EC (47.61 \%) and CMT (39.28 \%). However, the specificity of the of CMT (72.34) were higher than those of SCC (70.21\%), EC (59.57 \%) and pH (38.02\%). The accuracy of SCC, EC, $\mathrm{pH}$ and CMT was $71.75 \%$, $51.90 \%, 51.14 \%$ and $51.14 \%$, respectively.

The analysis of Kappa statistics revealed that SCC
Table 4: Analysis of the somatic cell count values in comparison with bacterial culture

Preglednica 4: Analiza števila somatskih celic $v$ primerjavi $z$ bakteriološkim testom

\begin{tabular}{llll}
\hline & \multicolumn{2}{l}{$\begin{array}{l}\text { Somatic cell count } \\
\text { values (cells/ml) }\end{array}$} \\
\cline { 2 - 4 } Values observed & $\geq 200000$ & $\geq 240000$ & $\geq 300000$ \\
\hline Sensitivity (\%) & 73.80 & 72.61 & 40.47 \\
Specificity (\%) & 40.42 & 70.21 & 74.46 \\
Positive predictive value (\%) & 68.88 & 81.33 & 73.91 \\
Negative predictive value (\%) & 46.34 & 58.92 & 41.17 \\
Accuracy (\%) & 61.83 & 71.75 & 52.67 \\
\hline
\end{tabular}

had a good agreement $(k=0.411)$ with the bacteriological culture examination. However, a poor concordances were observed between the bacteriological culture test and the $\mathrm{pH}, \mathrm{EC}$ and CMT tests with values of $(k=0.046)$, $(k=0.064)$ and $(k=0.099)$, respectively.

Furthermore, based on Chisquare statistic test, only the SCC had an agreement $(p<0.05)$ with the results of culture examination. However, there was significant difference $(p>0.05)$ between the bacteriological culture test and the $\mathrm{pH}, \mathrm{EC}$ and CMT tests.

The somatic cell count test showed the highest correlation $(r=0.415, p<0.05)$ with bacterial culture test, followed by CMT $(r=0.117, p>0.05)$, EC $(r=0.069, \quad p>0.05)$ and $\mathrm{pH}$ $(r=0.049, p>0.05)$, respectively which showed a poor positive correlation with bacterial culture.

The comparison of various indirect diagnostic tests characteristics between the different studies is shown in Table 6. The observed differences with the results of the other studies indicate a wide range of possible tests properties.

\section{DISCUSSION}

The knowledge and effectiveness of different screening tests to detect subclinical form of mastitis have long been acknowledged as an imperative to the success of mastitis control and treatment in livestock animals. Many previous studies were reported for various species such as goat (Ghasemzadeh-Nava et al., 2008), sheep (Pradiee et al., 2012) and cattle (Langer et al 2014; Reddy et al., 
Table 5: Comparison of considered thresholds characteristics, agreement and correlation values of various indirect tests in comparison with bacterial culture

Preglednica 5: Primerjava mejnih vrednosti, ujemanja in korelacij med različnimi posrednimi testi in bakteriološko kulturo

\begin{tabular}{|c|c|c|c|c|}
\hline \multirow[b]{3}{*}{ Values observed } & \multicolumn{4}{|c|}{ Threshold values } \\
\hline & $\mathrm{pH}$ & $\begin{array}{l}\text { Electrical conduc- } \\
\text { tivity }(\mathrm{mS} / \mathrm{cm})\end{array}$ & $\begin{array}{l}\text { California } \\
\text { mastitis test }\end{array}$ & $\begin{array}{l}\text { Somatic cell } \\
\text { count (cells } / \mathrm{ml})\end{array}$ \\
\hline & $\geq 6.55$ & $\geq 7.2$ & $\begin{array}{l}\text { Score trace = } \\
\text { CMT }(+)\end{array}$ & $\geq 240000$ \\
\hline Sensitivity (\%) & 66.66 & 47.61 & 39.28 & 72.61 \\
\hline Specificity (\%) & 38.02 & 59.57 & 72.34 & 70.21 \\
\hline Positive predictive value (\%) & 47.61 & 67.79 & 71.73 & 81.33 \\
\hline Negative predictive value (\%) & 57.44 & 38.88 & 40.00 & 58.92 \\
\hline Accuracy (\%) & 51.14 & 51.90 & 51.14 & 71.75 \\
\hline Kappa & 0.046 & 0.064 & 0.099 & 0.411 \\
\hline Chi-square ( $p$ value) & 0.577 & 0.427 & 0.181 & 0.000 \\
\hline R (Phi correlation) & 0.049 & 0.069 & 0.117 & 0.415 \\
\hline
\end{tabular}

Chi-square test with: $p<0.05$ indicates an agreement between the results obtained for the diagnostic tests and the result of bacterial culture test, $p>0.05$ indicates a disagreement between the results obtained for the diagnostic tests and the result of bacterial culture test.

2014). However, there is very little report about these aspects on sub-clinical mastitis in camels.

Bacterial culture is a standard method for examination of mastitis in camels (Tuteja et al., 2013). It may be carried out on individual quarter samples or on composite samples including milk from all quarters. In a mastitis control program, the cost of bacteriological culture in the laboratory can be greatly reduced by screening the

Table 6: Comparison of $\mathrm{pH}, \mathrm{EC}, \mathrm{CMT}$ and SCC characteristics Preglednica 6: Primerjava značilnosti pH, EC, CMT in SSC metod

\begin{tabular}{lllll}
\hline Authors & Test & Sensitivity & Specificity & Basis \\
\hline Current study & $\mathrm{pH}$ & 66.66 & 38.02 & Bacterial Culture \\
Langer et al (2014) (cows) & & 56.84 & 61.1 & Bacterial Culture \\
\hline Current study & & 47.61 & 59.57 & Bacterial Culture \\
Langer et al (2014) (cows) & EC & 25 & 87.1 & Bacterial Culture \\
Reddy et al (2014) (cows) & & 56.52 & 84.84 & Bacterial Culture \\
\hline Current study & & 39.28 & 72.34 & Bacterial Culture \\
Sharma et al. (2010) (cows) & & 86.07 & 59.70 & Bacterial Culture \\
Pradiee et al (2012) (ewes) & CMT & 28.67 & 87.06 & Bacterial Culture \\
Langer et al (2014) (cows) & & 60.1 & 62.7 & Bacterial Culture \\
Reddy et al (2014) (cows) & & 71.07 & 75.75 & Bacterial Culture \\
\hline Current study & & 72.61 & 70.21 & Bacterial Culture \\
Sharma et al. (2010) (cows) & & 88.60 & 97.76 & Bacterial Culture \\
Pradiee et al (2012) (ewes) & SCC & 13.33 & 95.29 & Bacterial Culture \\
Langer et al (2014) (cows) & & 39.8 & 84.8 & Bacterial Culture \\
Reddy et al (2014) (cows) & & 65.21 & 78.78 & Bacterial Culture \\
\hline
\end{tabular}

camels with the indirect tests first and then culturing the positive reactors (Abdurahman et al., 1995; Almaw and Molla, 2000). These tests are indirect and detect only presence of inflammatory changes. Moreover, the intensity of the inflammation can be estimated qualitatively by CMT and quantitatively by SCC. The two tests have been used as diagnostic tools to detect subclinical mastitis in camel (Eberlein, 2007; Saleh and Faye, 2011). Similarly, technique that examines change in the milk conductivity (Ali et al., 2016) or its $\mathrm{pH}$ could be used to detect mastitis in camel (Tuteja et al., 2003).

The results of present study indicate that the good combination of sensitivity and specificity of $\mathrm{pH}$ test was obtained while using a threshold of 6.55. However, our current findings are in disagreement with the findings of Tuteja et al. (2013) who reported that a threshold of 6.4 or more is indicative of sub-clinical mastitis in dairy camels. Sensitivity of $\mathrm{pH}$ test observed in present study was higher than that reported by Langer et al. (2014) for cows. Although, the specificity of this test was much lower than that reported by those authors, the low specificity observed for $\mathrm{pH}$ test suggests that $\mathrm{pH}$ of milk is not suitable method 
for detection of subclinical mastitis in camels. The $\mathrm{pH}$ of milk may depend on the nature of fodder and water availability (Gorban and Izzeldin, 1997). Similarly, other factors may affect milk $\mathrm{pH}$ such as milk yield, lactation stage, milk composition and waiting time between sampling and testing. However, Ali et al. (2016) reported an increase in $\mathrm{pH}$ of camel milk samples in subclinical infection when compared to non-infected animals.

The current study indicated that a threshold of $7.2 \mathrm{mS} / \mathrm{cm}$ showed the good combination of sensitivity and specificity of electrical conductivity. This finding is comparable with that reported by Ali et al. (2016). In the present study, sensitivity and specificity of electrical conductivity was lower than that reported by Reddy et al.(2014). Likewise, based on this result, electrical conductivity cannot be used as an indirect test to detect subclinical mastitis in camel. This finding was in line with the previous report (Younan et al., 2001; Eberlein, 2007). Mastitis is not the only circumstance that causes changes in milk electrical conductivity and non-mastitis related variation in electrical conductivity is a major drawback. Non-mastitis factors influencing electrical conductivity include milk temperature, density, water, fat, protein percentage and breed (Elobeid et al., 2015).

The threshold values on SCC and CMT in camel milk were recent and not common. According to Merin et al., (2004), the SCC values in infected udder are lower in camel compared to the other ruminants. The present study showed that the good combination of sensitivity and specificity of these tests was obtained with a thresholds of $240000 \mathrm{cell} / \mathrm{ml}$ and score trace of CMT was considered as positive, respectively. This finding is supported by the report of Alamin et al (2013) who suggested that a threshold of SCC more than $2.5 \times 105$ cells $/ \mathrm{ml}$ can be considered as indication of udder infection in camel. Sensitivity of CMT observed in our study was lower than that reported by Younan et al. (2001) which revealed a rate ranging from $68 \%-77 \%$ for major pathogen (S. agalactiae and S. aureus) in camel and that observed by Sharma et al. (2010) in cattle. The specificity of CMT concurs with the observations of Reddy et al. (2014) for cows but is lower than that reported by Younan et al. (2001) (91\%) for camel. The observed differences between the results of these studies indicate a wide range of possible CMT properties. This may be influenced by the subjectivity involved in interpreting the results of CMT. However, many researchers confirm that CMT can be used as a screening test to detect subclinical mastitis in camels (Saleh and Faye, 2011; Husein et al., 2013; Wanjohi et al., 2013).

In this study, SCC was found to be more accurate, sensitive, and specific than the CMT, pH and electrical conductivity tests compared to the bacteriological cul- ture. Kathiriya and Shah (2009) compared the accuracy of SCC, CMT and pH for the detection of subclinical mastitis in dairy camels and stated that SCC was the most accurate test after examination using bacteriological culture. In addition, previous reports have confirmed that milk SCC can be used as a screening test to detect subclinical mastitis in camels (Bekele and Molla, 2001; Saleh and Faye, 2011). However, Alamin et al. (2013) reported that the SCC couldn't be used for detection of subclinical mastitis in camel.

The analysis of statistical results revealed that the $\mathrm{pH}$, electrical conductivity and CMT test have a poor agreement ( $\mathrm{k}=0.046,0.064$ and 0.099 , respectively) and poor correlation ( $\mathrm{r}=0.049,0.069$ and 0.117 , respectively) with bacteriological examination. These results indicate that any single test may not be suitable in diagnosing sub-clinical mastitis. This finding is in agreement with previous studies (Younan et al., 2001, Bhatt et al., 2004 and Eberlein et al., 2007) who confirmed that electrical conductivity cannot be used for detection of subclinical mastitis in camels. However, many researchers (Abdel Gadir et al., 2006, Hawari and Hassawi, 2008 and Saleh and Faye 2011) reported that the positive correlation of CMT with the presence of mastitis pathogens in camel milk and stated that CMT is useful screening test in the detection of mastitis in camel and may serve to detect udder infected with major pathogens in a subclinical form. However, all of these studies subjected to cultural examination only the milk samples which had positive reaction on CMT.

In the present study only the SCC showed a good agreement $(k=0.411)$ and a good significant correlation ( $r=0.415, p<0.05)$ with the results of bacteriological culture. The value of the diagnostic test depends on its accuracy, sensitivity, specificity, predictive values, percentage agreement, and field applicability. In this study, SCC was found to be more accurate, sensitive, and specific than the other three tests ( $\mathrm{pH}, \mathrm{EC}$ and CMT) compared to the bacterial culture. Also, Guliye et al. (2002), Hawari and Hassawi (2008) reported that an increase in the number of somatic cells in camel milk is a good indication of the presence of pathogenic microorganisms in milk samples. Moreover, Kathiriya and Shah (2009) compared the accuracy of SCC, CMT and pH for the detection of subclinical mastitis in dairy camels and stated that SCC was the most accurate test after cultural examination. Similarly, Saleh and Faye (2011) confirm that SCC can be used as a screening test to detect subclinical mastitis in camels.

The observed discrepancy between the results of current study with those of other reports (Table 6) can be attributed to several possible factors such as animal species, subjective interpretation of the CMT and SCC results as well as the difference in the devices used for 
measurement of $\mathrm{pH}$ and electrical conductivity of milk samples.

\section{CONCLUSION}

It is concluded that the SCC was the most accurate and reliable diagnostic method following the cultural isolation for the detection of sub-clinical mastitis in dairy camels under field conditions. Therefore, the combination between the SCC and CMT tests might be used effectively for diagnosis of sub-clinical mastitis in dairy camels. Moreover, the current study stated that the CMT, $\mathrm{pH}$ and $\mathrm{EC}$ were a poor predictor of udder infections. Therefore, the use of any single test may not be reliable in diagnosing sub-clinical mastitis in dairy camels.

\section{AUTHORS' CONTRIBUTIONS}

This work was carried out in collaboration between all authors. Author LH conducted the study. Author HA designed the study and served as principal supervisor. Author BH and MSM searched for the literatures and participated in manuscript writing. Authors AA wrote the protocols. All authors read and approved the final manuscript.

\section{REFERENCES}

Abdel Gadir Atif, E., Hildebrant, G., Kleer, J. N., Molla, B., Kyule, M. N. \& Baumann, M. P. (2006). Comparison of California Mastitis Test (CMT), Somatic Cell Counts (SCC) and bacteriological examinations for detection of camel (Camelus dromedarius) mastitis in Ethiopia. Berliner und Münchener tierärztliche Wochenschrift, 119(1-2), 45-49.

Abdurahman, O. A., Agab, H., Abbas, B., \& Åström, G. (1995). Relations between udder infection and somatic cells in camel (Camelus dromedarius) milk. Acta Veterinaria Scandinavica, 36(4), 423-431.

Ahmad, S., Yaqoob, M., Bilal, M. Q., Muhammad, G., Yang, L.G., Khan, M. K., \& Tariq, M. (2012). Risk factors associated with prevalence and major bacterial causes of mastitis in dromedary camels (Camelus dromedarius) under different production systems. Tropical Animal Health and Production, 44(1), 107-112. doi:10.1007/s11250-011-9895-0

Alamin M. A., Alqurashi, A. M., Elsheikh, A. S., \& Yasin, T. E. (2013). Mastitis incidence and bacterial causative agents isolated from lactating she-camel (Camelus dromedaries). IOSR Journal of Agriculture and Veterinary Science, 2(3), 7-10. doi:10.9790/2380-0230710

Ali F., Hussain, R., Qayyum, A., Gul, S. T., Iqbal, Z., \& Hassan, M. F. (2016). Milk somatic cell counts and some hematobiochemical changes in sub-clinical mastitic dromedary she-camels (Camelus dromedarius). Pakistan Veterinary Journal, 36(4), 405-408.

Al-Juboori, A. A., Kamat, N. K., \& Sindhu, J. I. (2013). Prevalence of some mastitis causes in dromedary camels in Abu Dhabi, United Arab Emirates. Iraqi Journal of Veterinary Sciences, 27(1), 9-14.

Almaw, G., \& Molla, B. (2000). Prevalence and etiology of mastitis in camels (Camelus dromedaries) in Eastern Ethiopia. Journal of Camel Practice and Research, 7(1), 97-100.

Bekele T., \& Molla, B. (2001). Mastitis in lactating camels (Camelus dromedaries) in Afar Region, North-East Ethiopia. Berliner und Münchener tierärztliche Wochenschrift, 114(5-6), 169-172.

Bhatt L., Chahar, A., Tuteja, F. C., Tanwar, R. K., \& Verma, D. (2004). Therapeutic efficacy of enrofloxacin alone and in combination with levamisole in subclinical mastitis in camel. Journal of Camel Practice and Research, 11(2), 153-156.

Eberlein, V. (2007). Hygienic status of camel milk in Dubai (United Arab Emirates) under two different milking management systems (Doctoral dissertation). Ludwig-Maxmillians-Universit, Munich, Germany.

Elobied, A. A., Osman, A. M., Abu Kashwa, S. M., Ali, A. S., Ibrahim, M. T. \& Salih, M. M. (2015). Effect of parity and breed on some physico-chemical components of Sudanese camel milk. Research opinions in animal \& veterinary sciences, 5(1), 20-24. http://www.roavs.com/pdf-files/Issue-1-2015/20-24.pdf

Ghasemzadeh-Nava, H., Bokaee, S., Tajik, P., Mohammadsadegh, M., \& Esfandabadi, N. S. (2008). Sensitivity and Specificity of MAS-D-TEC to detect subclinical mastitis in sheep and goats. Proceedings, The $15^{\text {th }}$ Congress of FAVA. OIE Joint Symposium on Emerging Diseases, Bangkok, Thailand (pp. 21-22). Retrieved from http://161.200.35.61/ Data_files/ebook/FAVA2008/paperfile/PA009.pdf

Gonzalo, C., Ariznabarreta, A., Carriedo, J. A., \& San Primitivo, F. (2002). Mammary Pathogens and their relationship to somatic cell count and milk yield losses in dairy Ewes. Journal of Dairy Science, 85(6), 1460-1467. doi:10.3168/jds. s0022-0302(02)74214-8

Gorban, A. M. S., \& Izzeldin, O. M. (2001). Fatty acids and lipids of camel milk and colostrum. International Journal of Food Sciences and Nutrition, 52(3), 283-287. doi:10.1080/713671778

Guliye, A. Y., Van Creveld, C., \& Yagil, R. (2002). Detection of subclinical mastitis in dromedary camels (Camelus dromedarius) using somatic cell counts and the $\mathrm{N}$-acetyl-beta-Dglucosaminidase test. Tropical Animal Health and Production, 34(2), 95-104. doi:10.1023/a:1014324421258

Hawari, A. D., \& Hassawi, D. S. (2008). Mastitis in One humped She-Camels (Camelus dromedarius) in Jordan. Journal of Biological Sciences, 8(5), 958-961. doi:10.3923/ jbs.2008.958.961

Husein, A., Berihu, H., Abbisalem, H., \& Asamenew, T. (2013). Prevalence of camel (Camelus dromedaries) mastitis in Jijiga Town, Ethiopia. African Journal of Agricultural Research, 8(24), 3113-3120.

Kathiriya, J. B., \& Shah, N.M. (2009). A comparative study of different tests for diagnosis of subclinical mastitis in camels. Indian Journal of Animal Research 43(3), 191-193. 
Langer, A., Sharma, S., Sharma, N. K., \& Nauriyal, D. S. (2014). Comparative efficacy of different Mastitis markers for diagnosis of sub-clinical Mastitis in cows. International Journal of Applied Sciences and Biotechnology, 2(2), 121-125. doi:10.3126/ijasbt.v2i2.10191

Merin U., Sela, S., Rosen, B., Pinto, R., \& Leitner, G. (2004) Standards for camel milk. In B. Faye, \& P. Esenov (Eds.), Desertification combat and food safety: the added value of camel producers: Vol. 362. NATO Sciences Series, Life and Behavioural Sciences (pp. 152-158). Proc. Intern. Workshop, Ashkabad (Turkmenistan), 19-22 April 2004. IOS press Publ., Amsterdam.

NMC. (1987). Laboratory and field handbook on bovine mastitis. Madison: National Mastitis Council (NMC) Inc.

Pradieé J., Moraes, C. R., Gonçalves, M., Vilanova, M. S., Corrêa, G. F., Lauz, O. G., . . S Schmidt, V. (2012). Somatic Cell Count and California Mastitis Test as a diagnostic tool for subclinical mastitis in ewes. Acta Scientiae Veterinari 40(2), 1038.

Quinn P.J., M.E. Carter, B. Markey, and G.R. Carter. 1999. Clinical Veterinary Microbiology. London, England: Wolf publishing.

Reddy, B. S. S., Kumari, K. N., Reddy, Y. R., Reddy, M. V. B., \& Reddy, B. S. (2014). Comparison of different diagnostic tests in subclinical mastitis in dairy cattle. International Journal of Veterinary Science, 3(4), 224-228.

Saleh S. K., Faye, B. (2011). Detection of subclinical mastitis in dromedary camels (Camelus dromedaries) using somatic cell counts, california mastitis test and udder pathogen. Emirates Journal of Food and Agriculture, 17(1), 48-58. doi:10.9755/ejfa.v23i1.5312
Sharma N., Pandey, V., \& Sudhan, N. A. (2010). Comparison of some screening tests for detection of subclinical mastitis in dairy cows. Bulgarian Journal of Veterinary Medicine, 13(2), 98-103.

Tibary A., \& Anouassi, A. (2000). Lactation and udder disease. In: L. Skidmore, \& G. P. Adams (Eds.), Recent Advances in Camelid Reproduction. Retrieved from http://www.ivis.org, International veterinary Information Service

Tuteja, F. C., Dixit, S. K., Ghorui, S. K., Deen, A., \& Sahani, M. S. (2003). Prevalence, characterisation and antibiotic sensitivity of intramammary infections in camel. Journal of Camel Practice and Research, 10, 69-77.

Tuteja, F. C., Dixit, S. K., Patil, N. V., Suchitra Sena, D., \& Singh, S. (2013). Camel mastitis. A technical bulletin. Jorbeer, Shivbari, Bikaner-334001: National Research Centre on Camel.

Wanjohi, M., Gitao, C. G., \& Bebora, L. (2013). Subclinical mastitis affecting hygienic quality of marketed camel milk from North-Eastern Province, Kenya. Microbiology Research International, 1(1), 6-15.

Weisen J. P. (1974). La stratégie de la lutte antimammite. In : La prophylaxie des mammites (pp. 43-79). Paris, France: Vigot frères Éditeurs.

Younan, M., Ali, Z., Bornstein, S., \& Müller, W. (2001). Application of the California mastitis test in intramammary Streptococcus agalactiae and Staphylococcus aureus infections of camels (Camelus dromedarius) in Kenya. Preventive Veterinary Medicine, 51(3-4), 307-316. doi:10.1016/ s0167-5877(01)00228-8 